ORIGINAL PROF-2089

\title{
INCIDENCE OF PLACENTAL ABRUPTION;
}

\author{
Morbidity / mortality associated with it
}

Dr. Nailla Yousuf Memon, Dr. Firdous Mumtaz, Dr. Shaista Farooq.

ABSTRACT.....Objective: To determine the Incidence of Placental Abruption and the morbidity / mortality associated with it. Design: Prospective and Observational case Study. Setting \& Duration: Department of Obstetrics \& Gynecology, Liaquat University of Medical and Health Sciences Hyderabad, for a period of 15 months from January 2007 to March 2008. Patients \& Methods: Among all the antenatal patients delivered during the period under review, those suffering from Placental abruption were entered into this study by completing a proforma for each patient. After history, examination and initial management, investigations were carried out. These patients were managed on case to case basis depending on the progression of abruption and delivery. After delivery whether spontaneous or by cesarean section the condition of mother and subsequent complications were recorded and results analyzed on SPSS version 10. Results: During the period 15 months, 2760 patients were admitted to labour room /labour ward and delivered. Among these, 100 patients had abruption making an incidence of $2.89 \%$ per year. According to the degree of abruption 33 had mild, 50 had moderate and 17 had severe abruption. $42 \%$ had spontaneous vaginal delivery, and $52 \%$ underwent cesarean section. $36 \%$ of Abruptio patients, developed complications like shock, PPH and DIC. One (1\%) patient died in severe abruption. Conclusions: The incidence of Abruptio Placentae in this study is comparable to local studies and studies from developing countries, but is high in comparison to studies from developed countries. The maternal morbidity and mortality rate is not as high as in other studies.

Key words: Abruptio Placentae, Incidence, Morbidity, Mortality.

Article Citation

Memon NY, Mumtaz F, Farooq S. Incidence Of Placental Abruption; Morbidity / mortality associated with it. Professional Med J 2013;20(3): 422-428.

\section{INTRODUCTION}

Abruptio placentae is now universally adopted term for the condition that was previously known as accidental hemorrhage $^{1,2}$. Placental abruption is bleeding after premature separation of a normally situated placenta, usually after 20 weeks of pregnancy ${ }^{3,4}$.

It is a serious Obstetrical condition associated with an increased incidence of perinatal morbidity and mortality. The incidence of Abruptio placentae is less than 1 percent in USA, Europe and other developed countries, but it remains $2-8 \%$ in the developing world $^{5,6,7}$.

The abruptio placentae is graded according to the clinical classification, as mild (amount of vaginal bleeding less than $100 \mathrm{ml}$ ), moderate (amount 100$500 \mathrm{ml}$ ) and severe (amount more than $500 \mathrm{ml}$ ) and other criteria like uterine tone, fetal heart rate, coagulopathy and maternal status are also considered ${ }^{4}$.
The major complications of placental abruption are hemorrhagic shock, Disseminated intravascular coagulation, ischemic necrosis of the distal organs and postpartum haemorrhage ${ }^{1,2}$.

Few studies have been conducted on the frequency and complications of this condition.

The aim of this study is to know the frequency of this condition in our setting and to record the complications that are encountered in managing this type of obstetrical emergency.

\section{PATIENTS \& METHODS}

All booked and unbooked antenatal patients presenting in antenatal clinic or in emergency with signs and symptoms of Abruptio placentae were entered into this study.

\section{INCLUSION CRITERIA}

All pregnant women between 20 weeks and term with 
complain of abdominal pain/ backache and bleeding per vagina were included in this study.

\section{EXCLUSION CRITERIA}

Pregnant women having bleeding per vagina due to causes other than abruption like placenta previa, ruptured uterus, cervical polyp etc. were excluded from study.

A detailed history of these patients was taken, examination performed and findings entered into proforma. Relevant investigations were sent to laboratory and ultrasound examination of abdomen and pelvis was requested. Once diagnosed these patients were appropriately managed according to the severity of the condition and the condition of fetus monitored. The management consisted of either immediate delivery (SVD/LSCS) or the patient was kept under observation with monitoring and the supportive treatment till delivered.

The complications were dealt with as they developed. All these details were entered into questionnaire form which was completed separately for each individual case. All the data was entered into SPSS program and data was analysed after calculating frequencies, mean and standard deviation.

\section{RESULTS}

During the period under study, 2760 patients were admitted to labour room /labour ward and delivered. The mean age in this study was $29.4( \pm 4.1)$ years, the mean parity was $4.1( \pm 3.7)$ (Table-I). Among these, 100 patients had abruption making an incidence of $2.89 \%$ per year. Comparison of rate of abruption from different local as well as international studies has been shown in Table-Il. 33 had mild degree of abruption, 50 had moderate and 17 had severe abruption as shown in Table-III. Out of 36 who developed complications, $19(52.7 \%)$ went into shock, 12(33.3\%) suffered from postpartum hemorrhage (among these one developed acute renal failure, and two developed DIC). Overall $5(13.8 \%)$ patients developed DIC as shown in table-IV. 42 had spontaneous vaginal delivery, 52 underwent lower segment cesarian section, one patient died due to severe bleeding leading to DIC as shown in Figure 1.

\begin{tabular}{|l|c|c|c|c|c|c|}
\hline \multicolumn{1}{|c|}{ Variable } & $\begin{array}{c}\text { Test } \\
\text { Value }=\mathbf{0}\end{array}$ & df & $\begin{array}{c}\text { Sig. } \\
\text { (2-tailed) }\end{array}$ & \multicolumn{2}{c|}{$\begin{array}{c}\text { Mean } \\
\text { Difference }\end{array}$} & \multicolumn{2}{c|}{$\begin{array}{c}\text { 95\% Confidence interval } \\
\text { of the difference }\end{array}$} \\
\hline & $\mathbf{t}$ & & & & Lower & Upper \\
\hline Age in years & 70.926 & 99 & .000 & 29.43 & 28.6067 & 30.2533 \\
\hline Parity in number & 18.147 & 99 & .000 & 4.02 & 3.2854 & 4.7546 \\
\hline Gestation age & 84.464 & 99 & .000 & 34.98 & 34.1583 & 35.8017 \\
\hline Duration of Vaginal Bleed in hours & 3.071 & 99 & 0.003 & 22.34 & 7.9046 & 36.7754 \\
\hline
\end{tabular}

Table-I. Shows different variables with mean and $95 \%$ confidence interval.

\begin{tabular}{|l|c|c|c|c|}
\hline & N & Mean & Std. Deviation & Std. Error Mean \\
\hline Age & 100 & 29.4300 & 4.1494 & .4149 \\
\hline Parity & 100 & 4.02 & 3.7026 & 9.5426 \\
\hline Gestational Age & 100 & 34.9800 & 4.1414 & .4141 \\
\hline Vaginal Bleeding Duration & 100 & 22.3400 & 72.7509 & 7.2751 \\
\hline
\end{tabular}




\begin{tabular}{|c|c|c|c|c|c|}
\hline Author & Country & $\begin{array}{c}\text { Year of } \\
\text { Publication }\end{array}$ & $\begin{array}{c}\text { No: of } \\
\text { Deliveries }\end{array}$ & $\begin{array}{l}\text { No: of } \\
\text { Abruptio } \\
\text { Patients }\end{array}$ & Percentage \\
\hline KJ Noorani $^{5}$ & Pakistan & 1995 & 8766 & 630 & $7.18 \%$ \\
\hline Shamshad ${ }^{8}$ Begum & Pakistan & 2003 & & & $3.00 \%$ \\
\hline Sadia $Z^{6}$ & Pakistan & 2003 & & & $2.00 \%$ \\
\hline Naqvi $\mathrm{MM}^{9}$ & Pakistan & 2003 & & & $6.15 \%$ \\
\hline Nizam $K^{10}$ & Pakistan & 2004 & 1662 & 110 & $7.00 \%$ \\
\hline Musarrat $\mathrm{J}^{11}$ & Pakistan & 2004 & 3291 & 151 & $4.50 \%$ \\
\hline Iram Sarwar ${ }^{12}$ & Pakistan & 2006 & 1194 & 53 & $4.40 \%$ \\
\hline Nagina Fatima $^{13}$ & Pakistan & 2006 & 4497 & 102 & $2.26 \%$ \\
\hline This Study & Pakistan & 2007 & 2760 & 100 & $2.89 \%$ \\
\hline Dafallah SE ${ }^{14}$ & Sudan & 2004 & 15620 & 1028 & $6.50 \%$ \\
\hline Vigil DE ${ }^{15}$ & Panama & 2004 & & & $8.40 \%$ \\
\hline Tuthill DP ${ }^{16}$ & UK & 1999 & & & $2.07 \%$ \\
\hline Shiener $\mathrm{E}^{17}$ & Israel & 2002 & 5934 & 300 & $5.10 \%$ \\
\hline William MA ${ }^{18}$ & USA & 1991 & 10648 & 943 & $8.85 \%$ \\
\hline Shiener $\mathrm{E}^{19}$ & Israel & 2003 & 72995 & 219 & $0.30 \%$ \\
\hline Ananth $C^{20}$ & USA & 1999 & 1358623 & 8724 & $0.64 \%$ \\
\hline Ananth $C^{21}$ & USA & 2001 & & & $0.59 \%$ \\
\hline Ananth $C^{22}$ & USA & 2001 & 7508605 & & $0.65 \%$ \\
\hline Kavegard $\mathrm{M}^{23}$ & Sweden & 1986 & & & $0.44 \%$ \\
\hline Toivonen $\mathrm{S}^{24}$ & Finland & 2002 & & & $0.57 \%$ \\
\hline Tikanen $^{25}$ & Finland & 2006 & & & $0.42 \%$ \\
\hline Atef $Y^{26}$ & Tunis & 2005 & & & $0.34 \%$ \\
\hline Abu Heija ${ }^{27}$ & Jordan & 1998 & 18256 & 108 & $0.59 \%$ \\
\hline Thieba B ${ }^{28}$ & French & 2003 & & 177 & $0.96 \%$ \\
\hline
\end{tabular}




\begin{tabular}{|l|c|c|c|c|c|}
\hline \multicolumn{1}{|c|}{ Abruptio Grade } & Frequency & Percent & Valid Percent & Cumulative Percent & Column-I \\
\hline Mild & 33 & 33 & 33 & 33 & \\
\hline Moderate & 50 & 50 & 50 & 83 & \\
\hline Severe & 17 & 17 & 17 & 100 & \\
\hline & 100 & 100 & 100 & & \\
\hline
\end{tabular}

Table-III. Showing the degrees of abruption

\begin{tabular}{|l|c|c|}
\hline \multicolumn{1}{|c|}{ Complications } & Number & Percentage \\
\hline Shock & 19 & $52.77 \%$ \\
\hline Postpartum haemorrhage (one developed acute renal failure), two developed DIC & 12 & $33.33 \%$ \\
\hline DIC (one developed acute renal failure) & 05 & $13.88 \%$ \\
\hline Total & 36 & $100 \%$ \\
\hline
\end{tabular}

Table-IV. Showing rate of different complications.

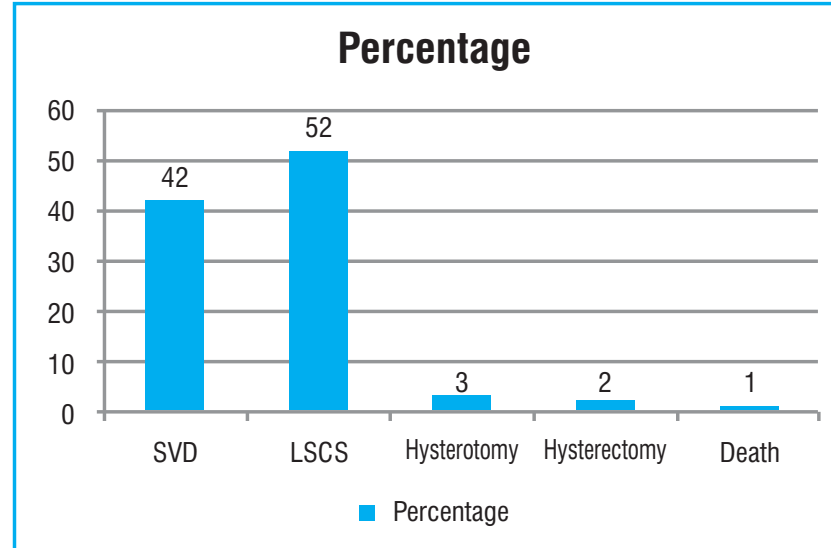

Figure 1: Showing Maternal outcome

\section{DISCUSSION}

This study on abruptio placentae, and its complications was conducted in the department of Obstetrics \& Gynaecology, Liaquat University of Medical \& Health Sciences Hospital Hyderabad, from January 2007 to March 2008.

During this period a total 2760 deliveries were conducted and out of these, the patients of abruptio placentae recorded were 100 , resulting in an incidence of $2.89 \%$ per year.
The studies from Pakistan and other developing countries show an incidence between $2 \%$ and $8.5 \%$ (Table-II). Recent studies from USA by Ananth et al. show the incidence of less than $1 \%{ }^{20-22}$. This is also confirmed from studies of European and other countries (Table-II). It is an obvious fact that the incidence was higher in the past, and it has definitely come down to less than $1 \%$ in USA. This is also confirmed from studies by Sheiner et al, and other recent studies from USA (Table-II). This fact emphasizes that knowing the risk factors in a given population, and taking measures to prevent these risk factors particularly by antenatal care can decrease the incidence, and thereby reducing the perinatal morbidity and mortality.

All the patients presented with some degree of vaginal bleeding. The mean duration of vaginal bleeding was 22.34 hours. According to the degree of abruption 33 had mild, 50 had moderate and 17 had severe abruption (Table-III).

42 patients delivered their babies by spontaneous vaginal delivery, whereas 52 patients under went 
caesarian section (Figure1). Karegard and et al show a caesarian section frequency of $74.6 \%$ with a perinatal mortality of $20.2 \%^{23}$. Similarly Vigil $\mathrm{De}^{15}$ show $71.4 \%$ frequency and Tikkanen et al have shown a $91 \%$ Csection rate with a perinatal mortality $9.2 \%{ }^{25}$. This high rate of caesarian section is probably a factor towards early management and decreased perinatal mortality

The maternal morbidity was $36 \%$ and the complications are shown in (Table-IV). Most common complication was Shock affecting 19 patients, followed by Postpartum haemorrhage which affected 12 patients. Other common complication was disseminated intravascular coagulation (DIC) which occurred in 5 patients and these patients were managed with fresh frozen plasma and fresh blood transfusions. One patient (1\%) died in severe abruption, as the blood could not be arranged in time for this patient and she died two hours after arrival.

The maternal morbidity and mortality rate is comparable to a local study by Nagina Fatima et $a 1^{13}$. It is not as high as compared to other studies ${ }^{11,12}$. In one study by Thiebaet $\mathrm{al}^{28}$ the maternal death rate was about $3.9 \%$, despite low incidence of abruptio (9.61/1000). In another study by Shad H Deering ${ }^{29}$ maternal death by abruptio has been shown to be $6 \%$. Vigil De et.al ${ }^{15}$, conclude that extensive monitoring of the clinical status of the mother was associated with low maternal morbidity and the absence of maternal deaths.

\section{CONCLUSIONS}

The incidence of abruptio placentae in this study is $2.89 \%$ per year, which is comparable to local studies but is high as compared to western studies. The maternal morbidity and mortality rate is not as high as shown in other studies.

\section{Copyright@ 18 Feb, 2013.}

\section{REFERENCES}

1. Abu-Heija A, al-Chalabi H, el-lloubani N. Abruptio placentae: risk factors and perinatal outcome. $\mathrm{J}$ ObstetGynaecol Res. Apr 1998;24(2):141-4. [Medline].

2. Oyelese $\mathrm{Y}$, Ananth CV. Placental abruption. Obstet Gynecol. Oct 2006;108(4):1005-16.

3. Ananth CV, Oyelese Y, Yeo L, Pradhan A, Vintzileos AM. Placental abruption in the United States, 1979 through 2001: temporal trends and potential determinants. Am J Obstet Gynecol. Jan 2005;192(1):191-8. [Medline].

4. Plunkett J, Borecki I, Morgan T, Stamilio D, Muglia LJ. Population-based estimate of sibling risk for preterm birth, preterm premature rupture of membranes, placental abruption and pre-eclampsia. BMC Genet. Jul 8 2008;9:44. [Medline]. [Full Text].

5. KJ Noorani, M Noorani, Prevalence of acute renal failure in patients developing abruption placentae as a consequence of PIH. Pakistan J Obstet Gynecol Jan 1995;8(1):15-16.

6. Saadia Z Khan AZ, N aheed F. Fetal outcome varies with different grades of Placental Abruption. Ann Kind Edward Med Coll Mar 2003;9(1):40-2.

7. Vigid De Gracia P, Montufar RC, Smith A. Pregnancy and severe chronic hypertension: maternal outcome. Hypertens Pregnancy 2004;23(3): 285-93.

8. Begum S. Age and parity related problems affecting outcome of labor in grand multiparas. Pakistan J Med Res Dec 2003; 42(4):179-84.

9. Naqvi MM. Outcome of Twin Pregnancy in booked versus unbooked cases. J Coll Physicians Surg Pak Sep 2003;13(9):498-500.

10. Nizam K, Memon N, Laghari MS. Renal failure - A dreadful complication seen in patients with Abruptio Placentae. Pak Armed Forces Med J, 2004;54(1):84-7.

11. MusarratJabeen, FoziaGul. Abruptio Placentae: risk factors and perinatal outcome. JPMI Dec 2004;18 (4):669-76.

12. IramSarwar, Aziz unNisaAbbasi, Ansa Islam. Abruptio placentae and its complications at Ayub Teaching Hospital Abbottabad. J Ayub Med Coll Abbottabad 2006; 18(1). 
13. Nagina Fatima Liaquat, Tabussum Shoaib, SamiaShuja. A study of abruptio placenta. J Surg Pakistan Mar 2006;11(1):27-30.

14. Dafallah SE, Babikir HE. Risk factors predisposing to abruptio placentae. Maternal and fetal outcome. Saudi Med J, 2004 Sep;25(9):1237-40.

15. Vigid De Gracia P, Montufar RC, Smith A. Pregnancy and severe chronic hypertension: maternal outcome. Hypertens Pregnancy 2004;23(3): 285-93.

16. Tuthill D.P, Stewart J.H, Coles E.C et al. Maternal cigarette smoking and pregnancy outcome. Paediatric \& Perinatal Epidemiology, July 1999; 13(3):245253.

17. Sheiner E, ShohamVardi I, Hallak M et al. Incidence, Obstetric risk factors and pregnancy outcome of preterm placental abruption: a retrospective analysis. JMatern-Fetal-Neonatal-Med, 2002 Jan;II (l):34-9.

18. Williams MA, Mitendrof R, Monson RR. Chronic hypertension, cigarette smoking and abruptio placentae. Am. JObstet Gynecol1994 Jun;170(6): 1595-9.

19. Sheiner E, ShohamVardi I, Hallak M et al. Placental abruption in term pregnancies: clinical significance and obstetric risk factors. J-MatemFetal_NeonatalMed, 2003 Jan;13(I):45-9.

20. Ananth CV, Smulian JC, Vintzileos AM. Incidence of placental abruption In relation to cigarette smoking and hypertensive disorders during pregnancy: a meta analysis of observational studies. Obstet Gynecol 1999Apr;93(4):622-8.

21. Ananth CV, Smulian JC, Demissie K et al. Placental abruption among singleton and twin births in the United States: risk factor profiles. Am-J-Epidemiol 2001Apr 15;153(8):771-8.

22. Ananth CV, Wilcox AJ, Placental abruption and perinatal mortality in the United States. Am J Epidemiol. 2001 Feb 15; 153(4): 332-7.

23. M Karegard and G Gennser. Incidence and recurrence rate of abruptio placentae in Sweden. Obstet Gynecoll 986;67:532-28.

24. Toivonen S, Henonen S, Anttila M et al. Reproductive risk factors, Doppler findings and out come of affected births in placental abruption: a population based analysis. Am J Perinato12002 Nov; 19(8):45160.

25. Tikkanen $M$, Nuutila $M$, Hiilesmaa $V$ Paavonen et al. Clinical presentation and risk factors of placental abruption. Acta Obstet GynecolScand 2006;85(6): 700-5.

26. Atef $Y$, Nizar BA, Hasen M Faouzi GM. Abruptio placentae. Tunis Med 2005 0ct;83(10):603-6.

27. Abu-Heija A, al-Chalabi H, el-lloubani N. Abruptio placentae: risk factors and perinatal outcome. J Obstet Gynecol Res 1998 Apr; 24(2):141-4.

28. Thieba B, Lankailde J, Akotionga M, Kyelem C et al. Abruptio placentae: epidemiological, clinical and prognostic aspects with respect to a 177 case series.

29. Shad H. Deering Abruptio Placentae. [Online webpage] August 31, 2005[cited May 30 2006]. Available from: URL:http://www.emedicine.com/ emerg/.htm 


\section{AUTHOR(S):}

1. DR. NAILLA YOUSUF MEMON

DGO, M.S (OBS/GYN)

Senior Registrar OBS/GYN

SMBBMU / CMC, Larkhana.

2. PROF. DR. FIRDOUS MUMTAZ

FCPS (OBS/GYN)

Professor of OBS/GYN

Incharge Gynae Unit-II

LUMHS, Jamshoro.
3. DR. SHAISTA FAROOQ

FCPS (OBS/GYN)

Professor of OBS/GYN

LUMHS, Jamshoro.

Correspondence Address:

Dr. Nailla Yousuf Memon

Bunglow No: A-5, Professor's Residence,

SMBBMU / CMC Larkhana.

Article received on: 22/09/2012

Accepted for Publication: 18/02/2013

Received after proof reading: 25/03/2013

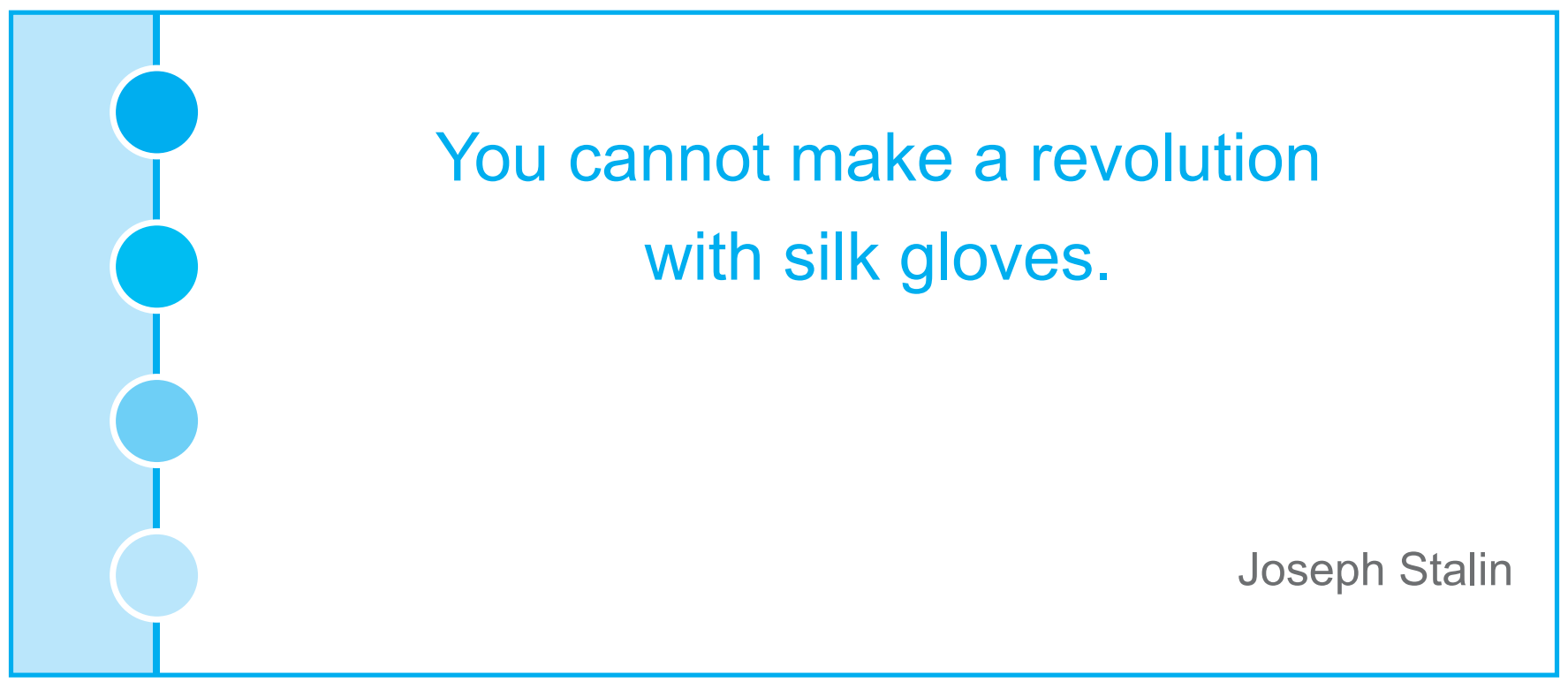

